\title{
INVENTÁRIO EXTRAJUDICIAL: LACUNA LEGISLATIVA SOBRE ATOS QUE DEPENDEM DE AUTORIZAÇÃO JUDICIAL
}

\author{
Flávia Izac Veroneze ${ }^{1}$ \\ Rogerio Franco Batista ${ }^{2}$ \\ Júlio César Franceschet ${ }^{3}$
}

\begin{abstract}
Resumo
O presente artigo visou discorrer sobre a ausência de previsão legal na legislação brasileira no tocante à prática de atos pelo inventariante no curso do inventário extrajudicial, mais especificamente, aqueles previstos no artigo $n^{\circ} 619$ do Código de Processo Civil. Diante disso, o artigo teve como objetivo estudar a intenção do legislador ao editar a lei 11.411/07, que visa a desburocratização e descongestionamento do Poder Judiciário e a possibilidade da prática de atos pelo inventariante independentemente de autorização judicial, desde que devidamente autorizado por todos os demais herdeiros e interessados.
\end{abstract}

Palavras-chave: Processo Civil. Alvará Judicial. Inventariante. Autorização. Desburocratização.

\section{EXTRAJUDICIAL INVENTORY: LEGISLATIVE GAP ON ACTS THAT DEPEND ON JUDICIAL AUTHORIZATION}

\begin{abstract}
The purpose of this article was to analyze Brazilian law, which does not foresee the practice of some acts by the administrator of the inheritance in the extrajudicial liquidation, especially the acts presents in number 619 of the Brazilian Civil Procedure Code. Thus, the article analyzed the legislator's intention with Law 11.417/07, that removed certain procedures from the Judiciary, making the resolution of conflicts faster. This article also analyzed if the inheritance administrator can to practice, in the extrajudicial liquidation, some acts without the judge's authorization, however, with the agreement of all the heirs.
\end{abstract}

Keywords: Civil Procedure. Inheritance. Extrajudicial liquidation. Procedures. Judiciary.

\section{INTRODUÇÃO}

\footnotetext{
${ }^{1}$ Mestranda em Direito pela UNIARA. E-mail: fiveroneze@uniara.edu.br.

${ }^{2}$ Mestrando em Direito pela UNIARA. E-mail: rfbatista@uniara.edu.br.

${ }^{3}$ Doutor em Direito Civil pela Universidade de São Paulo (USP). Mestre em Direito Civil pela Universidade do Estado do Rio de Janeiro (UERJ). Professor dos cursos de graduação em Direito e Mestrado Profissional em Direito da Universidade de Araraquara (UNIARA). Juiz de Direito. e-mail: jcfranceschet@uniara.edu.br.
} 
A Constituição Federal garante em seu artigo $5^{\circ}, \mathrm{XXXV}$, o direito fundamental de acesso à justiça ao estabelecer que "a lei não excluirá da apreciação do Poder Judiciário lesão ou ameaça a direito". Nesse contexto de proteção ao direito, quando se busca a tutela do Estado, espera-se uma resposta rápida e eficiente advinda do Poder Judiciário.

Em contraposição aos princípios da celeridade e eficiência, a realidade é que o Poder Judiciário não consegue julgar de forma satisfatória o enorme número de processos que tramitam nas mais diversas esferas judiciais, causando um sentimento de frustração àqueles que procuram resolver seus conflitos pela via judicial. Nesse sentido, Minelli e Cachapuz afirmam que:

É sabido, entretanto, que o crescente volume de processos, muitas vezes de baixa
complexidade, torna esse sistema cada vez mais congestionado, moroso e
ineficiente, o que acaba gerando uma significativa restrição ao direito de acesso à
justiça daqueles que realmente dependem de uma resposta do Estado-juiz para a
solução de seus conflitos (MINELLI; CACHAPUZ, 2018, p.1).

Diante desse problema, o Estado vem adotando medidas para desburocratização e descongestionamento dos Tribunais, cujo foco é a desjudicalização de atos que antes eram de exclusividade do Poder Judiciário, atribuindo-se aos Serviços Registrais e Notariais competência para solucionar problemas em casos que não há conflitos e nem interesse de incapazes.

Algumas atividades que antes eram exclusivas do Judiciário, foram descentralizadas também, de forma alternativa, aos cartórios extrajudiciais, cujo deslocamento dessas atribuições teve como objetivo trazer agilidade aos atos e desafogar os Tribunais, que estão abarrotados de processos, que muitas vezes, sequer possuem conflito entre as partes (CHAVES; REZENDE, 2011).

Essa política de desjudicalização, com a publicação de diversas leis, representa uma vantajosa contribuição por parte do legislador para reduzir o conglomerado de processos e viabilizar soluções mais rápidas para as ações pretendidas (OLIVEIRA; MORONG, 2018). Nesse conglomerado de leis, que visam a desburocratização de atos e desafogo do judiciário, citamos a lei 8.560/92, que trata do reconhecimento de paternidade diretamente nos Cartórios de Registro Civil das Pessoas Naturais, a lei 9.514/97, que dispõe sobre o procedimento da alienação fiduciária, a lei 10.931/04, que autoriza a retificação administrativa do Registro Público e a lei 11.441/07, que autoriza a realização de inventário e partilha, separação e divórcio nas serventias extrajudiciais. Das leis e medidas de deslocamento de atos e 
atribuições da esfera judicial para a extrajudicial, o foco do presente artigo é a Lei 11.411/07, que alterou o Código de Processo Civil e possibilitou o trâmite do Inventário e partilha e da separação judicial ou divórcio pela via extrajudicial, sem a necessidade de judicialização do procedimento.

O procedimento extrajudicial de inventário e partilha foi devidamente autorizado pelo legislador no artigo 982 do antigo Código de Processo Civil (artigo 610, $\S 1^{\circ}$, do Novo Código de Processo Civil), in verbis: "se todos forem capazes e concordes, poderá fazer-se o inventário e a partilha por escritura pública, a qual constituirá título hábil para o registro imobiliário". Como se nota, os requisitos para o processamento do inventário pela via extrajudicial são a inexistência de testamento válido e eficaz ${ }^{4}$, que todas as partes sejam capazes e que haja consenso quanto à partilha e divisão dos bens e direitos. Outro requisito imprescindível é que as partes estejam assistidas por advogado ou defensor público ( $\left(2^{\circ}\right.$, do artigo 610, do Código de Processo Civil).

Além dos impedimentos ou restrições legais, consistentes na existência de testamento ou incapacidade das partes, explicitamente enumerados no artigo 610, caput, do Código de Processo Civil, que vedam o trâmite extrajudicial do inventário e partilha, detectamos também uma restrição subjetiva e implícita, não prevista em lei, que se consubstancia na questão econômica das partes.

Em outras palavras, verificamos na prática notarial, situações em que os sucessores, muito embora capazes e concordes com a realização do inventário e partilha pelo cartório, não possuem condições e liquidez financeira para suportar as despesas do processo e necessitam alienar um bem do acervo hereditário ou fazer o levantamento de valores no transcorrer do inventário para quitar os impostos incidentes sobre a transmissão ou pagar os emolumentos cartorários e o advogado, caso não esteja assistido por defensor público. Apenas para registro, em caso de hipossuficiência, as partes ficarão isentas do pagamento dos emolumentos devidos aos tabeliães e registradores ${ }^{5}$. Assim, este artigo busca investigar a

\footnotetext{
${ }^{4}$ Em alguns Estados a existência de testamento não impede a lavratura da escritura pública de inventário e partilha, sendo ele revogado, declarado nulo ou caduco, ou ainda mediante ordem judicial, desde que devidamente registrado. Provimento Conjunto 93/2020 - CGJ/MG, em seu artigo: 224, §1: É possível a lavratura de escritura pública de inventário e partilha nos casos de testamento revogado, declarado nulo ou caduco ou, ainda, por ordem judicial.

${ }^{5}$ No Estado de Minas Gerais, a isenção de pagamento dos emolumentos está prevista no Provimento Conjunto 83/2020 - Código de Normas da Corregedoria de Justiça do Estado de Minas Gerais, em seus artigos 139 a 141.
} 
incapacidade financeira temporária, traduzida pela iliquidez econômica no trâmite do inventário. $\mathrm{O}$ foco da análise foi os bens deixados pelo falecido e que poderiam ser levantados ou alienados para pagamento de despesas. Questiona-se possíveis empecilhos à intenção do legislador ao adotar medidas para redução de processos judiciais e desafogo do Judiciário. Em suma, a pesquisa foi conduzida pela estratégia da pesquisa documental, dentro da lógica qualitativa, por meio do método indutivo.

A condução da pesquisa compreendeu: (i) pesquisa bibliográfica; (ii) análise bibliográfica; (iii) redação; e (iv) revisão. A pesquisa bibliográfica consistiu na leitura das obras e textos referentes ao assunto. Prioridade foi dada à bibliografia fundamental. A fase de redação compreendeu: a redação provisória e a redação definitiva acrescida de todos os elementos pré-textuais (capas, apresentação, introdução, notas explicativas, apêndices, bibliografia, glossário, etc.) e digitação. Por fim, foi feita a revisão de todo o material escrito a fim de se avaliar a clareza e a objetividade do trabalho. Nesta etapa, foram realizadas desde correções ortográficas até o remodelamento da estrutura das argumentações mais complexas. Procedeu-se, então, à digitação final. É importante registrar, ainda, que foram conjugados os métodos histórico e comparativo. Através do primeiro pretendeu-se abordar as principais fontes de registro existentes quanto ao tema, em especial a doutrina, nacional e estrangeira, e a jurisprudência. E, já que a discussão aqui proposta parte de certas contradições, o método comparativo foi utilizado quando da confrontação de ideais e teorias. Quanto aos modelos teóricos de investigação, apresentou-se como mais pertinentes o hermenêutico e o argumentativo. Neste, foi priorizado o aspecto sociológico e naquele o filosófico.

\section{DA AUTORIZAÇÃO JUDICIAL DENTRO DO PROCESSO DE INVENTÁRIO}

A transmissão causa mortis está devidamente amparado pelo nosso ordenamento jurídico ${ }^{6}$ e para que o sucessor possa dar efetividade ao seu direito hereditário deverá ingressar com uma ação judicial denominada inventário ou arrolamento. $\mathrm{O}$ direito de ação está devidamente previsto pela nossa Constituição Federal em seu artigo $5^{\circ}$, inciso XXXV, segundo o qual "a lei não excluirá da apreciação do Poder Judiciário lesão ou ameaça de direito".

\footnotetext{
${ }^{6}$ Constituição Federal, artigo $5^{\circ}$, XXX: É garantido o direito de herança.
} 
Nosso Poder Judiciário está devidamente estruturado e organizado de acordo com o Capítulo III, Seção I, artigos 92 a 126, da Constituição Federal, sendo que na esfera cível, as atribuições do juiz de direito estão previstas no Título IV, Capítulo I, artigo 139 e seguintes do Código de Processo Civil, que trata dos Poderes, dos Deveres e da Responsabilidade, sendo que no caput, já se demonstra o papel do magistrado em relação à lide proposta ao definir que "o juiz dirigirá o processo conforme as disposições deste código (...)”.

Assim, ao provocar o judiciário, a parte busca o reconhecimento ou preservação de um direito ou interesse que entende ser titular e que deve ser analisado de forma imparcial e justa, cujo teor da decisão gere segurança jurídica para as partes envolvidas e para a sociedade. Nesse sentido, Theodoro Junior destaca:

À parte, diante do Estado-juiz, dispõe de um poder jurídico, que consiste na faculdade de obter a tutela para os próprios direitos ou interesses, quando lesados ou ameaçados, ou para obter a definição das situações jurídicas controvertidas. É o direito de ação, de natureza pública, por referir-se a uma atividade pública, oficial, do Estado (THEODORO JUNIOR, 2018, p. 187).

Uma vez distribuída a ação, o processo passa a ter seu desenvolvimento por impulso oficial $^{7}$ e, por consequência, o juiz passa a ser o administrador do conflito, podendo praticar todos os atos previstos na legislação processual até a resolução da lide. Dentre tais poderes, podemos destacar aqueles previstos nos incisos I a X do artigo 139 do Código de Processo Civil $^{8}$. Desta forma, o juiz deve bem dirigir o processo judicial, observar o conteúdo das normas pertinentes, assegurar o tratamento igualitário das partes, dar andamento célere ao

\footnotetext{
${ }^{7}$ CPC. Art. $2^{\circ}$. O processo começa por iniciativa da parte e se desenvolve por impulso oficial, salvo as exceções previstas em lei.

${ }^{8}$ Art. 139. O juiz dirigirá o processo conforme as disposições deste Código, incumbindo-lhe: I - assegurar às partes igualdade de tratamento; II - velar pela duração razoável do processo; III - prevenir ou reprimir qualquer ato contrário à dignidade da justiça e indeferir postulações meramente protelatórias; IV - determinar todas as medidas indutivas, coercitivas, mandamentais ou sub-rogatórias necessárias para assegurar o cumprimento de ordem judicial, inclusive nas ações que tenham por objeto prestação pecuniária; V - promover, a qualquer tempo, a autocomposição, preferencialmente com auxílio de conciliadores e mediadores judiciais; VI - dilatar os prazos processuais e alterar a ordem de produção dos meios de prova, adequando-os às necessidades do conflito de modo a conferir maior efetividade à tutela do direito; VII - exercer o poder de polícia, requisitando, quando necessário, força policial, além da segurança interna dos fóruns e tribunais; VIII - determinar, a qualquer tempo, o comparecimento pessoal das partes, para inquiri-las sobre os fatos da causa, hipótese em que não incidirá a pena de confesso; IX - determinar o suprimento de pressupostos processuais e o saneamento de outros vícios processuais; X - quando se deparar com diversas demandas individuais repetitivas, oficiar o Ministério Público, a Defensoria Pública e, na medida do possível, outros legitimados a que se referem o art. $5^{\circ}$ da Lei $n^{\circ} 7.347$, de 24 de julho de 1985 , e o art. 82 da Lei $\mathrm{n}^{\circ}$ 8.078, de 11 de setembro de 1990, para, se for o caso, promover a propositura da ação coletiva respectiva.
} 
processo e reprimir os atos contrários à dignidade da Justiça (THEODORO JUNIOR, 2018, p. 479).

Dentro do âmbito de observação das normas que norteiam o processo, o juiz pode autorizar a alienação de bens no curso do inventário, seja para pagar dívidas, para fazer a conservação e melhoramentos de bens do espólio ou qualquer outra circunstância que enseje a necessidade de venda de bens. Essa autorização está condicionada um pedido do inventariante, com a oitiva dos interessados, conforme prescreve o artigo 619 do Código de Processo Civil.

A figura do inventariante é muito importante para o andamento do processo de inventário, pois, ao mesmo são atribuídos poderes para representar o espólio em juízo ou fora dele, administrar os bens deixados pelo falecido, prestar as primeiras e últimas declarações dentro do processo, exibir documentos relacionados ao inventário, apresentar testamento, trazer à colação bens recebidos pelo herdeiro ausente, renunciante ou excluído, prestar constas da sua gestão e, finalmente, requerer a declaração de insolvência (CPC, art. 618) ${ }^{9}$.

O inventariante, dentro da sua administração, poderá ainda, desde que autorizado pelos interessados, requerer ao juiz o respectivo alvará judicial para alienar bens de qualquer espécie, transigir em juízo ou fora dele, pagar dívidas do espólio e fazer as despesas necessárias à conservação e o melhoramento dos bens do espólio em caso de necessidade $\left(\mathrm{CPC}\right.$, art. 619) ${ }^{10}$ Assim, existindo patrimônio a ser inventariado, a falta de recursos econômicos dos sucessores para pagamento do imposto de transmissão ou as dívidas do espólio poderá facilmente ser solucionada no curso da ação judicial, uma vez que basta a autorização judicial para que o inventariante possa efetuar o levantamento de valores ou alienar algum bem que integra o acervo hereditário para cumprir tais obrigações.

\footnotetext{
${ }^{9}$ Art. 618: I - representar o espólio ativa e passivamente, em juízo ou fora dele, observando-se, quanto ao dativo, o disposto no art. $75, \S 1^{\circ}$; II - administrar o espólio, velando-lhe os bens com a mesma diligência que teria se seus fossem; III - prestar as primeiras e as últimas declarações pessoalmente ou por procurador com poderes especiais; IV - exibir em cartório, a qualquer tempo, para exame das partes, os documentos relativos ao espólio; V - juntar aos autos certidão do testamento, se houver; VI - trazer à colação os bens recebidos pelo herdeiro ausente, renunciante ou excluído; VII - prestar contas de sua gestão ao deixar o cargo ou sempre que o juiz lhe determinar; VIII - requerer a declaração de insolvência.

${ }^{10}$ Art. 619. Incumbe ainda ao inventariante, ouvidos os interessados e com autorização do juiz: I - alienar bens de qualquer espécie; II - transigir em juízo ou fora dele; III - pagar dívidas do espólio; IV - fazer as despesas necessárias para a conservação e o melhoramento dos bens do espólio.
} 
Esse pedido de alienação de bens ou levantamento de valores no curso do inventário deve estar devidamente fundamentado e, caberá ao juiz, conceder ou não a autorização para a venda ou recebimento de valores antes de finda ação proposta ${ }^{11}$.

\section{DA ESCRITURA PÚBLICA DE INVENTÁRIO EXTRAJUDICIAL}

A princípio, cumpre esclarecer que o inventário judicial está previsto no artigo $610^{12}$, caput, do Código de Processo Civil e o seu procedimento nos artigos 611 a 667, enquanto o inventário extrajudicial tem previsão legal nos parágrafos $1^{\circ}$ e $2^{\circ}$, do artigo 610 , do mesmo Código Processual ${ }^{13}$. O procedimento para a lavratura pública de inventário extrajudicial está previsto na Resolução no 35, de 24/04/2007, do Conselho Nacional de Justiça (CNJ), que disciplinou a aplicação da lei 11.441/07 pelos serviços notariais e de registro. Com a publicação da Resolução n ${ }^{\circ}$ 35, as Corregedorias Gerais de Justiça dos Estados inseriram nos respectivos Códigos de Normas dos Serviços Notariais e Registrais as orientações necessárias à prática dos atos notariais de inventário extrajudicial e de separação e divórcio ${ }^{14}$. A finalidade do inventário, independentemente de ser judicial ou extrajudicial, é a mesma, ou seja, a distribuição do patrimônio do falecido aos seus sucessores, porém, cada procedimento tem suas peculiaridades e forma de condução. Na via judicial temos um processo e na extrajudicial uma escritura pública.

No procedimento judicial o juiz conduz o processo, nomeia e destitui inventariante, faz exigências, determina citações e notificações, ordena a juntada de documentos ou a prática de atos, autoriza atos, decide sobre pontos controvertidos, fiscaliza o recolhimento de tributos e, finalmente, homologa a partilha com a expedição do competente formal de partilha. Nota-

\footnotetext{
${ }^{11}$ Art. 612. O do juiz decidirá todas as questões de direito desde que os fatos relevantes estejam provados por documento, só remetendo para as vias ordinárias as questões que dependerem de outra prova.

${ }^{12}$ Artigo 610: Havendo testamento ou interessado incapaz, proceder-se-á ao inventário judicial.

${ }^{13} \S 1^{\mathrm{o}}$. Se todos forem maiores e concordes, o inventário e a partilha poderão ser feitos por escritura pública, a qual constituirá documento hábil para qualquer ato de registro, bem como para levantamento de importância depositada em instituições financeiras.

$\S 2^{\circ}$. O tabelião somente lavrará a escritura pública se todas as partes interessadas estiverem assistidas por advogado ou defensor público, cuja qualificação e assinatura constarão no ato notarial.

${ }^{14}$ No Estado de Minas Gerais as normas para a lavratura do inventário e partilha estão previstas nos artigos 205 a 235 do Provimento $n^{\circ}$ 93/2020 - Código de Normas da Corregedoria Geral de Justiça do Estado de Minas Gerais.
} 
se que há uma sequência de atos, um verdadeiro e legítimo processo. Na esfera extrajudicial o inventário é formalizado por meio de um único ato notarial, a escritura pública. As partes envolvidas apresentam ao tabelião de notas toda a documentação para que este possa formalizar a vontade das partes e expedir o respectivo traslado, que servirá para a transferência dos bens do de cujus aos seus respectivos sucessores.

Importante esclarecer que o inventário extrajudicial tem a mesma validade do judicial, pois, é lavrado perante o tabelião de notas, cujos serviços prestados são dotados de publicidade, autenticidade, segurança e eficácia ${ }^{15}$, sendo os atos por eles realizados resguardados pela fé pública, ou seja, uma forte presunção de sua veracidade (CENEVIVA, 2014, p. 24).

Para Sardinha, os notários e registradores atuam de forma preventiva, assegurando a autenticidade, segurança, eficácia e publicidade dos atos jurídicos, como forma de manter a paz social (SARDINHA, 2018, p. 58). Por ser um serviço de ordem técnica, o notário tem a função de receber a manifestação de vontade das partes, qualificar juridicamente esta vontade, rechaçando as ilicitudes que porventura contenha e instrumentalizando o ato jurídico adequado a dar vazão àquela vontade (BRANDELLI, 2007, p. 121).

Essa intervenção pelo notário nos atos que deva dar forma jurídica, que trata o artigo $6^{\circ}$, da Lei $8.935 / 94^{16}$, corresponde em compreender as intenções e objetivos pretendidos pelos declarantes, culminando na lavratura do instrumento público adequado para formalizar a vontade manifestada, de forma que traga aos interessados e à sociedade a segurança jurídica desejada.

Após a captação da vontade dos declarantes, o tabelião deverá redigir e formalizar o instrumento adequado, cujos atos que podem ser praticados pelo notário estão inseridos no rol do artigo $7^{\circ}$, da Lei 8.935/94, ou seja, lavrar escrituras, procurações públicas, testamentos públicos, atas notariais; aprovar testamentos cerrados, autenticar cópias e reconhecer firmas ${ }^{17}$.

\footnotetext{
${ }^{15}$ Lei 8.935/94. Art. $1^{\circ}$ : Serviços notariais e de registro são os de organização técnica e administrativa destinados a garantir a publicidade, autenticidade, segurança e eficácia dos atos jurídicos

${ }^{16}$ Art. $6^{\circ}$ Aos notários compete: I - formalizar juridicamente a vontade das partes; II - intervir nos atos e negócios jurídicos a que as partes devam ou queiram dar forma legal ou autenticidade, autorizando a redação ou redigindo os instrumentos adequados, conservando os originais e expedindo cópias fidedignas de seu conteúdo; III - autenticar fatos.

${ }^{17}$ Art. $7^{\circ}$ Aos tabeliães de notas compete com exclusividade: I - lavrar escrituras e procurações, públicas; II lavrar testamentos públicos e aprovar os cerrados; III - lavrar atas notariais; IV - reconhecer firmas; V autenticar cópias.
} 
Os tabeliães e registradores exercem ainda um controle da legalidade dos atos que lhe forem submetidos e por meio de sua atuação, será conferida segurança jurídica ao ato realizado, advinda da fé pública da qual são investidos e do efeito da publicidade (MINELLI; CACHAPUZ, 2018). A escolha da via extrajudicial não é obrigatória, tampouco viola o direito de ação dos interessados. Nesse sentido, Montenegro Filho discorre:

O inventário e partilha extrajudicial não infringem o direito de ação, pois seu uso não é obrigatório, mas faculdade conferida aos herdeiros do de cujus, que podem preferir não instaurar o processo de inventário no seu modo tradicional, realizando a divisão do patrimônio do autor da herança em cartório, através de escritura pública, sem as angústias que cercam a tramitação dos processos de inventário, sobretudo pelo aspecto do tempo de duração (2018, p. 533).

Em contraposição aos procedimentos, nota-se que o juiz dirige o processo, enquanto ao notário não é atribuído esse poder, pois, a princípio processo não há. O que se pratica na esfera extrajudicial é a formalização jurídica da vontade das partes por meio da escritura pública (art. $6^{\circ}$, I, da Lei 8.935/94).

Da mesma forma que a sentença judicial, a escritura pública lavrada em cartório extrajudicial se constituirá em documento hábil para qualquer ato de registro, bem como para levantamento de importância depositada em instituições financeiras ${ }^{18}$.Assim, independentemente da via escolhida, o formal de partilha ou a escritura pública vão produzir os mesmos efeitos na sociedade, cujos instrumentos estarão revestidos de fé pública e especialmente segurança jurídica.

\section{DOS ATOS DO INVENTARIANTE (ART. 619 DO CPC) E O PROBLEMA DE SUA APLICAÇÃO NO ÂMBITO EXTRAJUDICIAL}

Independentemente da via escolhida para tramitação do inventário, a nomeação do inventariante é obrigatória nos dois procedimentos. Na esfera judicial a nomeação se dá por ordem do magistrado, conforme artigo 617, do Código de Processo Civil, in verbis "o juiz nomeará inventariante na seguinte ordem”, já na esfera extrajudicial, a obrigatoriedade está prevista no artigo 11, da Resolução n ${ }^{\circ} 35$, do Conselho Nacional de Justiça - CNJ, segundo o qual: "é obrigatória a nomeação de interessado, na escritura pública de inventário e partilha,

${ }^{18}$ Artigo 610, § 1, CPC 
para representar o espólio, com poderes de inventariante, no cumprimento de obrigações ativas ou passivas pendentes, sem necessidade de seguir a ordem prevista no art. 617 do Código de Processo Civil”.

Por haver consenso, no inventário extrajudicial a nomeação do inventariante é de livre escolha dos sucessores, cabendo ao tabelião tão somente a formalização da vontade das partes mediante a lavratura da escritura pública de nomeação de inventariante. No Estado de Minas Gerais, o procedimento encontra-se previsto no artigo 208, do Provimento Conjunto $\mathrm{n}^{\mathbf{o}}$ 93/2020, da Corregedoria Geral de Justiça, o qual determina que “quando se fizer necessário qualquer ato preparatório ao inventário, poderá ser nomeado inventariante extrajudicial para o cumprimento de obrigações do espólio, mediante escritura pública declaratória autônoma assinada por todos os interessados". As atribuições do inventariante estão elencadas nos artigos 618 e 619, do Código de Processo Civil, sendo que os atos deste último artigo (619) dependem de autorização judicial.

Quanto aos atos condicionados à autorização judicial, não há previsão expressa da sua prática na esfera extrajudicial. O legislador foi omisso nessa questão, ficando o tabelião de notas restrito à disposições do artigo 11 , da Resolução $n^{\circ} 35$, do CNJ, que dispõe que: "É obrigatória a nomeação de interessado, na escritura pública de inventário e partilha, para representar o espólio, com poderes de inventariante, no cumprimento de obrigações ativas ou passivas pendentes, sem necessidade de seguir a ordem prevista no art. 617 do Código de Processo Civil".

Como se nota, quando as partes optam pela escritura pública de inventário, devem nomear inventariante para representar o espólio, porém, seus poderes estão limitados a cumprir obrigações ativas ou passiva pendentes. Não há na legislação qualquer previsão expressa para que o inventariante possa alienar bens, transigir em juízo, pagar dívidas ou fazer despesas para a conservação dos bens do espólio, mesmo que todos os herdeiros o autorizem (art. 619, CPC). Essa lacuna legislativa, que não estabeleceu regras para que o inventariante pudesse administrar ou alienar bens do espólio, impede a busca pela via extrajudicial quando há uma incapacidade ou iliquidez financeira por parte dos sucessores.

\section{DA (IN)CAPACIDADE FINANCEIRA E O IMPACTO NA ESCOLHA DO INVENTÁRIO JUDICIAL OU EXTRAJUDICIAL}

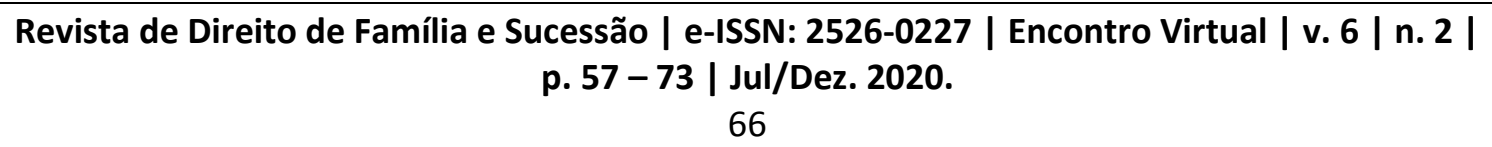


No tocante à faculdade das partes em escolher a via para o processamento do inventário causa mortis, temos que as medidas adotadas pelo Estado para desburocratizar e descongestionar o Poder Judiciário podem se tornar ineficazes em relação à falta de capacidade financeira ou liquidez dos herdeiros do falecido, muito embora capazes e concordes em realizar o inventário por escritura pública.

Como o recolhimento dos tributos deve anteceder à lavratura da escritura pública19, há casos em que as partes necessitam efetuar o levantamento de valores depositados em instituições financeiras em nome do falecido para poderem pagar todas as despesas cartorárias do inventário e, também, dos impostos incidentes sobre o ato praticado. Como já explanado, quando o processo é judicial, o juiz autoriza o inventariante, mediante alvará judicial, a efetuar o levantamento de valores ou alienação de bens para pagamento de dívidas do espólio. O mesmo não ocorre no extrajudicial, pois, o tabelião não tem poder jurisdicional, não manda ou determina, apenas formaliza a vontade das partes. A nosso ver, não há lógica na seguinte situação:

a) Pratica-se todos os atos preparatórios para a lavratura da escritura de inventário perante o tabelionato de notas, com a apresentação de todas as certidões fiscais, certidão negativa de testamento, certidões de propriedade e a apuração do imposto devido;

b) Sem recursos financeiros para recolher o tributo, os herdeiros, de posse da guia de itcd, ingressam no judiciário para requerer uma autorização judicial para levantar valores deixados pelo de cujus para que possam efetuar o pagamento do imposto de transmissão causa mortis, cujo inventário tramita pelo cartório de notas.

É fato que, quando as partes se deparam com a falta de recursos para custear o inventário e tendo a necessidade de se levantar valores ou alienar bens de titularidade do de cujus, fatalmente a escolha será pela via judicial, pois, mediante autorização judicial conseguirão os recursos necessários para dar andamento ao inventário.

Já na esfera extrajudicial, tal mecanismo não pode ser aplicado, pois em que pese haver consenso e autorização para que o inventariante aliene bens ou levante valores do falecido, o tabelião não encontra respaldo jurídico na legislação para poder expedir o documento público competente para a prática de tais atos.

\footnotetext{
${ }^{19}$ Resolução 35 - CNJ. Art. 15. O recolhimento dos tributos incidentes deve anteceder a lavratura da escritura.
} 
Nessas situações, em que todas as partes são capazes e concordes com o inventário e partilha, porém, sem condições financeiras para custear as despesas do inventário, a autorização judicial poderia ser substituída por uma escritura declaratória assinada por todos os herdeiros, autorizando expressamente o inventariante a sacar valores ou alienar bens do espólio para pagamento de dívidas do falecido ou para recolher o imposto de transmissão causa mortis. O que ocorre quando há a opção pelos cartórios é que somente após a lavratura da escritura pública é que este poderá ser utilizado para levantamento de valores em instituições financeiras ou alienar bens, que já não mais pertencem ao espólio.

Como se nota, não há previsão legal que autorize as partes a levantar valores de titularidade do falecido perante instituições financeiras por qualquer outro instrumento extrajudicial que não seja a escritura pública de inventário já finalizada. Assim, embora o legislador tenha editado a lei no intuito de desafogar o Judiciário, na prática o que se nota é a inviabilidade do trâmite dos inventários pela via extrajudicial em razão da incapacidade financeira das partes, uma vez que se veem impedidas e impossibilitadas de buscar recursos no próprio patrimônio do inventariado, seja para quitar dívidas do espólio, pagamento do imposto de transmissão e demais despesas decorrentes do próprio procedimento de inventário.

Pondera-se que diante da falta de regulamentação dos atos do inventariante na esfera extrajudicial, coube à Primeira Vara de Registros Públicos do Estado de São Paulo, no ano de 2.012, trazer uma luz ao problema, ao decidir que uma vez autorizado por todos os herdeiros, não há necessidade de expedição de alvará judicial para que o inventariante aliene bens do espólio, para cumprir obrigação feita pelo falecido em vida:

$1^{\text {a }}$ VRP|SP: Registro. Escritura Pública de Inventário e Partilha. Cumprimento de obrigações do Espólio. Alvará. Desnecessidade. O consenso dos herdeiros substitui a autorização judicial. Do contrário, esvaziaria o intuito da lei de desburocratizar o procedimento. Porém, deve haver a indicação do compromissário comprador no ato. A manutenção da negativa do registro - nesse ponto - acarreta a procedência da dúvida, que não comporta procedência ou improcedência parcial. Dúvida procedente.

Na sua fundamentação, o juiz Carlos Henrique André Lisboa ${ }^{20}$ evidencia que:

A intenção do legislador, ao criar a figura do inventário extrajudicial, foi justamente facilitar e agilizar o procedimento de transferência do patrimônio em razão da morte. Todavia, caso o alvará seja exigido para a realização de

\footnotetext{
${ }^{20}$ Juiz de Direito da $1^{\text {a }}$ Vara de Registros Públicos de São Paulo.
} 
qualquer ato por parte do representante do espólio escolhido consensualmente no momento da lavratura da escritura de inventário, o escopo de desburocratizar o procedimento não será alcançado.

$\mathrm{Na}$ mesma decisão, criou-se o entendimento de que havendo acordo entre os sucessores, não haveria necessidade de autorização judicial, pois, o consenso teria o condão de substituir a autorização pelo juiz, conforme se verifica a seguir:

Desnecessário, no caso, a obtenção de alvará judicial para a lavratura da escritura por parte do representante do espólio. Isso porque a nomeação feita no momento da lavratura da escritura de inventário e partilha, que pressupõe consenso dos herdeiros (art. 982 do Código de Processo Civil), substitui a autorização judicial.

Na decisão, há uma exaltação à finalidade da lei 11.411/07, cuja intenção do legislador ao transferir o inventário para a esfera extrajudicial, foi facilitar e agilizar o procedimento de transferência do patrimônio em razão da morte do inventariado e que, caso o alvará fosse exigido para a realização de qualquer ato por parte do inventariante, escolhido consensualmente no momento da lavratura da escritura de nomeação de inventariante ou do inventário, o escopo de desburocratizar o procedimento não seria alcançado.

Posteriormente, no ano de 2.015, em processo similar de suscitação de dúvida registral, cujo objeto foi a recusa do Oficial Registrador da cidade de Avaré, Estado de São Paulo, em registrar um bem imóvel pertencente a pessoa falecida e que fora alienado pelo inventariante sem a devida autorização judicial, também se consolidou o entendimento da desnecessidade de alvará judicial ${ }^{21}$. Nesse caso, o relator do acórdão, Hamilton Elliot Akel, cujo voto foi acompanhado por todos os demais Desembargadores, decidiu que estando o inventariante autorizado por todos os herdeiros a alienar bens do espólio, em razão de cumprimento de obrigação feita pelo falecido em vida, não haveria a necessidade da expedição de alvará judicial, ementa:

Registro de imóveis - Dúvida - Escritura pública de compra e venda de imóvel prometido à venda pelo falecido - exigência de alvará judicial autorizando a outorga - Desnecessidade, em razão da lavratura de escritura pública em que se nomeou pessoa com poderes de inventariante para cumprir as obrigações pendentes do de cujus - Recurso provido.

\footnotetext{
${ }^{21}$ CSM/SP. Apelação nº 0000228-62.2014.8.26.0073.
} 
Nessa mesma decisão, o relator faz um paralelo quanto aos procedimentos adotados no inventário judicial e no extrajudicial, que mostra uma evolução quanto ao entendimento dos poderes do inventariante:

\begin{abstract}
Antes da chegada do inventário extrajudicial (Lei n $11.441 / 07)$, não havia opção: o inventário e todas as providências relativas aos bens e obrigações (ativas ou passivas) do espólio tinham de passar pelo crivo do juízo do inventário. Assim, se os herdeiros quisessem, por exemplo, alienar determinado imóvel do falecido antes da partilha, tinham de requerer a expedição de alvará daquele juízo. Contudo, a superveniência do inventário extrajudicial modificou esse cenário. Se todos forem capazes, estiverem de acordo e não houver testamento, podem optar pela lavratura de escritura pública de inventário e partilha, na qual, além da divisão dos quinhões aos herdeiros, pode-se deliberar sobre as dívidas e obrigações pendentes do falecido, as quais serão cumpridas por pessoa com poderes de inventariante nomeada pelos herdeiros.
\end{abstract}

Como se vê, o próprio Judiciário entende que há uma mudança no cenário jurídico, pois, com a entrada em vigor da Lei 11.441/07, caso as partes queiram alienar algum bem do falecido no curso do inventário, poderiam fazê-lo mediante a lavratura de uma escritura pública de autorização para que o inventariante pudesse praticar o ato. Claro que essas autorizações no âmbito extrajudicial devem ter o acompanhamento e fiscalização do tabelião de notas, pois, as partes poderiam se utilizar do mecanismo para alienar bens ou levantar valores para fins escusos, que não a finalização do inventário.

\title{
6 CONSIDERAÇÕES FINAIS
}

Evidencia-se que este artigo foi inserido na temática "Gestão de Conflitos". Esta é uma temática inovadora e com grande potencial de exploração em pesquisas cientificas, havendo tão somente dois programas de mestrados profissionais alinhados a essa temática, sendo um, a proposta da UNIARA, no estado de São Paulo, e outro a proposta da Universidade de Fortaleza - UNIFOR, no estado do Ceará. Nota-se que a área de concentração do direito que discute as questões da gestão de conflitos está voltada para o estudo da gestão como instrumento de transformação das práticas profissionais no sistema judiciário. Contempla questões do âmbito da judicialização e da desjudicialização, incluindo a gestão dos conflitos, desde os métodos de prevenção, tais como a comunicação e a negociação, que reforçam a importância do diálogo; até os modelos extrajudiciais de solução de conflitos, tais como a conciliação, mediação e arbitragem, que promovem a celeridade

\footnotetext{
Revista de Direito de Família e Sucessão | e-ISSN: 2526-0227 | Encontro Virtual | v. 6 | n. 2 |

p. $57-73$ | Jul/Dez. 2020. 
processual e funcionam também, como instrumentos de justiça. Discute também, o papel da justiça comunitária e suas contribuições no processo de resolução de conflitos de modo participativo e legítimo, além da investigação dos procedimentos aplicados pelo Poder Judiciário e as políticas de inovação de conflitos estabelecidos pelo Conselho Nacional de Justiça.

Ao esboçar este artigo constatou-se que que a complexidade dos problemas gerados pela conjugação entre acesso à justiça, judicialização e dinâmica dos institutos de direito, remete, necessariamente a uma abordagem relacional e sistêmica que orienta a produção de pesquisas inovadoras, de apoio à prática da solução de conflitos, capazes de contribuir para a celeridade e dinamicidade das estruturas judiciárias e institutos de justiça. E é exatamente neste contexto que o Inventário Extrajudicial se reveste de importância.

Nota-se ainda que esta modalidade de atuação apresenta lacuna legislativa, preponderantemente, sobre atos que dependem de autorização judicial à luz do artigo $\mathrm{n}^{\circ} 619$ do Código de Processo Civil. Em suma, nota-se que diante da omissão do legislador em regulamentar as atribuições do inventariante, que dependem de autorização judicial (artigo 619, do CPC), no âmbito dos cartórios extrajudiciais, o objetivo de desburocratização e descongestionamento do Judiciário fica em xeque quando o falecido deixa patrimônio e também deixa herdeiros com incapacidade financeira, pois a necessidade de se levantar valores ou alienar bens do autor da herança para pagar impostos e despesas cartorárias direcionam a escolha pela via judicial.

O fato é que o tabelião não tem poderes para ordenar o saque ou alienação de bens, pois a lei lhe confere tão somente a atribuição de formalizar a vontade das partes; ele não dirige o processo, apenas analisa os documentos, observa o recolhimento dos tributos incidentes e lavra o instrumento adequado.

Desta forma, defendemos uma mudança na legislação processual para autorizar o inventariante a proceder ao levantamento de valores para pagamento de dívidas do espólio e/ou recolhimento do imposto causa mortis, desde que autorizado por todos os demais herdeiros, em substituição da autorização judicial.

\section{REFERÊNCIAS}


$1^{\text {a }}$ VRP/SP. Processo no 0011976-78.2012.8.26.0100 - Carlos Henrique André Lisboa - Juiz de Direito da $1^{\text {a }}$ Vara de Registros Públicos de São Paulo). Disponível em https://cnbmg.org.br/tj-mg-provimento-conjunto-n-93-2020-atualiza-o-codigo-de-normasque-regulamenta-os-servicos-notariais-e-de-registro-de-minas-gerais.;

BRANDELLI, Leonardo. Teoria geral do direito notarial, 2. ed. São Paulo: Saraiva, 2007;

BRASIL. Código de Processo Civil. Disponível em: http://www.planalto.gov.br;

BRASIL. Lei 8.935/94. Disponível em: http://www.planalto.gov.br.

CENEVIVA, Walter. Lei dos Notários e dos Registradores Comentada. $9^{\text {a }}$ Ed. São Paulo: Saraiva, 2014;

CGJ/MG. Provimento Conjunto 93/2020 - CGJ/MG. Disponível em: http://cnbmg.org.br/wp-content/uploads/2020/06/codigodenormas.pdf

CHAVES, Carlos Fernando Brasil; REZENDE, Afonso Celso F. Tabelionato de Notas e o Notário Perfeito. $6^{\text {a }}$ Ed. São Paulo: Millennium, 2011;

CNJ. Resolução $n^{\circ} 35$ - Conselho Nacional de Justiça. Disponível em: http://www.atos.cnj.jus.br.

CSM/SP. Apelação $\quad \mathbf{n}^{\circ} \quad$ 0000228-62.2014.8.26.0073. Disponível em: https://www.26notas.com.br/blog/?p=10942;

MINELLI, Daiane Schwabe. CACHAPUZ, Rozane da Rosa. O Papel das Serventias Extrajudiciais no Aprimoramento do Acesso à Justiça. Revista Cidadania e Acesso à Justiça. e-ISSN: 2526-026x, Porto Alegre/v.4/n.2/p.01-19;

MONTENEGRO FILHO, Misael. Direito Processual Civil, 13. ed. - São Paulo: Atlas, 2018;

OLIVEIRA, Rafaela Parpinéli. MORONG, Fábio Ferreira. A Desjudicalização e os Atos de Inventário e Usucapião Extrajudiciais. Colloquium Socialis, Presidente Prudente, v.02, n. Especial 2, Jul/Dez, 2018, p. 30-36. DOI: 10.5747/cs.2018.v02.nesp2.s0252. 
SARDINHA, Cristiano de Lima Vaz. Cartórios e Acesso à Justiça: A Contribuição das Serventias Extrajudiciais para a Sociedade Contemporânea, como Alternativa ao Poder Judiciário. $1^{\text {a }}$ Edição. Bahia: Editora Jus Podivm, 2018;

THEODORO JUNIOR, Humberto. Curso de Direito Processual Civil. 59 ed. rev. e atual. e ampl. Rio de Janeiro. Forense, 2018; 